Prima: Jurnal Pendidikan Matematika

Vol. 5, No. 1, January 2021, pp. 35-46

P-ISSN: 2579-9827, E-ISSN: 2580-2216

Web: http://jurnal.umt.ac.id/index.php/prima

\title{
USING REALISTIC MATHEMATICS EDUCATION IN MATHEMATICAL PROBLEM-SOLVING ABILITY BASED ON STUDENTS' MATHEMATICAL INITIAL ABILITY
}

\author{
Ilma Nurfadilah ${ }^{1}$, Hepsi Nindiasari ${ }^{2}$, Abdul Fatah $^{3}$ \\ Universitas Sultan Ageng Tirtayasa, Jl. Raya Jakarta, Kota Serang, Banten (0254) 280330, Indonesia \\ e-mail: ilmanurf29@gmail.com
}

\begin{abstract}
The 2013 curriculum requires students to master the cognitive domains from analysis to evaluation. The fact is not all students have the same cognitive development. Junior high school students, it turns out that students who think concretely must see in real terms, so the learning approach used in this study has to lead students to be active in learning. One of the active learning approaches is Realistic Mathematics Education (RME). This study is experimental research. The goals of this study are: 1 . Is the mathematical problem-solving abilities of students who used the RME approach better than students who used the scientific approach? 2. Determine whether there is an interaction between the learning approach and the mathematical-initial ability (high, medium, low) on students' mathematical problem-solving abilities. The results showed: 1 . The mathematical problem-solving abilities of students who used the RME approach was better than students who used the scientific approach; 2 . There is no interaction between the learning approach and mathematical-initial abilities (high, medium, low) on students' mathematical problem-solving abilities.
\end{abstract}

Keywords: RME, problem-solving, mathematical-initial ability, learning approach

\begin{abstract}
Abstrak
Kurikulum 2013 mengharuskan siswa menguasai ranah kognitif mulai dari analisis hingga evaluasi. Faktanya tidak semua siswa memiliki perkembangan kognitif yang sama. Siswa SMP ternyata siswa yang berpikir secara konkret harus melihat secara nyata, sehingga pendekatan pembelajaran yang digunakan dalam penelitian ini harus mengarahkan siswa untuk aktif dalam pembelajaran. Salah satu pendekatan pembelajaran aktif adalah Realistic Mathematics Education (RME). Penelitian ini merupakan penelitian eksperimental. Tujuan dari penelitian ini adalah: 1. Apakah kemampuan pemecahan masalah matematis siswa yang menggunakan pendekatan RME lebih baik daripada siswa yang menggunakan pendekatan saintifik? 2. Menentukan apakah ada interaksi antara pendekatan pembelajaran dan kemampuan awal matematika (tinggi, sedang, rendah) terhadap kemampuan pemecahan masalah matematika siswa. Hasil penelitian menunjukkan: 1. Kemampuan pemecahan masalah matematis siswa yang menggunakan pendekatan RME lebih baik daripada siswa yang menggunakan pendekatan saintifik; 2 . Tidak ada interaksi antara pendekatan pembelajaran dan kemampuan awal matematika (tinggi, sedang, rendah) terhadap kemampuan pemecahan masalah matematika siswa.
\end{abstract}

Kata kunci: RME, pemecahan masalah, kemampuan awal matematis, pendekatan pembelajaran

\section{INTRODUCTION}

Student-centered learning today is not a difficult thing, there are many models and approaches that teachers can use. The government also supports this with the implementation of the 2013 curriculum in each school. The 2013 curriculum learning models include discovery learning, inquiry learning, problem-based learning, and project-based learning. All of these models performed students to be active in the learning process. It does not only require students to be active in the learning process but also cognitive abilities. 
According to Bloom's Taxonomy, the cognitive domain has six levels in the thinking process, starting from the lowest level to the highest level, including knowledge (C1), understanding (C2), application (C3), analysis (C4), synthesis (C5), and evaluation. (C6). The cognitive domain after revision is remembering (C1), understanding (C2), applying (C3), analyzing (C4), evaluating (C5), and creating (C6).

The 2013 curriculum required students to accomplish the cognitive domains of $\mathrm{C} 4$ to C6. Students have not the same cognitive development; this is based on Piaget's theory that the mind of school-age children develops gradually and has started to develop thoughts logically. But in junior high school students there are still students who think concretely, must see in real terms, so that the learning approach is under this theory and it can direct students be came actively in learning, that is Realistic Mathematics Education (RME) approach.

The development of life is continually changing, so every student has an opportunity and choice to determine his future. The opportunities and choices can be realized if they are able to understand and do mathematic. With a strong mastery of mathematics would be able to survive in any conditions and be ready to compete in the future. The students should be competent in understanding and problem-solving in order to learn competitively in the future. Suratmi (2017) stated that students should have good problem solving skills that help them in the learning process in solving problems. One of them is math. It has a very important role. Problem-solving or learning methods can be trained and improved in learning activities in math.

However, now, mathematical problem solving is still a complicated matter for students. The results of the Program for International Student Assessment (PISA) and Trends in International Mathematics and Science Study (TIMSS), the problem-solving ability of Indonesian students is still low. The PISA survey (2015: 5) showed that Indonesia is ranked 64th out of 72 participating countries, while the last TIMSS survey in 2015 stated that Indonesia is ranked 45 th out of 50 countries.

Sugiman, et al. (2009) also have explained that problems often found in the field related to problem-solving abilities include: (1) there was a wrong perception of problem-solving. Many opinions solving mathematical problems is often identical to using mathematical formulas. The fact is that math problems in handbooks are not entirely problem-solving problems. There are many questions in handbooks that only practice numeracy skills or 
students' skills in using formulas. On the other hand not all math questions are mathematical problem solving questions; (2) students' lack of mathematical problem solving abilities, referring to the PISA test results; (3) the learning process that can guide and exercise students was not be able to solve problems. It has not received an adequate portion. Various findings in the field indicated a weakness in implementing mathematics learning because learning activities did not prepare students to learn to solve problems but only acquired new knowledge.

A mathematical approach that is oriented in real problems and emphasizes students' meaning in learning is the Indonesian Realistic Mathematics Education (PMRI) approach (Hendri, Zulkardi, \& IIma, 2007). The students' aim in learning can be interpreted that students are involved directly in learning so that they have a learning experience. It is connected with Fitriana (2010) research that the mathematics learning approach that links children's experiences to mathematical concepts is realistic mathematics education (PMR).

In strengthening mathematical concepts. The students need good mathematical initial abilities, because it affected in students' success of learning. It has a common knowledge in mathematics related to another mathematic materials that were arranged hierarchically, so the previous material becomes a prerequisite for the next material (Kusumawati, 2013).

Students' mathematical-initial abilities in solving mathematical problems have a very important role. Arend (2008) revealed that students' mathematical initial ability (KAM) is an important prerequisite to engage in the following study well. The emerge ideas often develops gradually, so it is a necessary to get enough ability to build a comprehensive mathematical concept of information obtained previously. If students do not accomplish the material prerequisites (previous knowledge) and students have difficulty mastering the required material. The students' initial ability is the student's learning achievement in the previous material so that in the class, students can be grouped into three groups based on their previous ability: the high, medium, and low ability groups.

As an analogy, students who have low previous capability would be more challenging to acquire new knowledge or assimilate new concepts associated with their prior knowledge. Meanwhile, students who have high previous abilities tend to receive information quickly and associate it with their information, so the learning process occured. In other words, in 
mathematic, teachers need to pay attention to the beginning of students' mathematical abilities.

As mathematical initial ability in this research is the prerequisite ability supporting learning social arithmetic material in seventh grade. In this study, the previous capability is needed to see the level of high, medium or low and mathematical understanding and mathematical problem solving approach after learning through RME.

Many our daily lives are closely linked to the social arithmetic and it was possible to do research on the semester (according syllabus). Estate issues is relating to the social arithmetic used as initial learning. So that, it can help students at the beginning of the learning process. Following the research expressed by Haji in Hernawati (2016), the problem-solving ability, understanding ability, and attitudes taught through the realistic mathematics education approach are significantly better than the usual approach.

Much research has been done before on RME, including by Yaya and Sugiman (2010), the research focused on problem solving mathematical junior high school students with the conclusion that approach realistic mathematics (PMR) increases. To be learning higher than students who received regular on students' overall learning and all school levels. Studies related to the RME approach have been done to measure and rise the mathematical problem solving skills, but there is no researcher seen from the students' mathematical initial abilities.

\section{METHODS}

This study used a true experimental research design with a design form: The Randomized Pretest-Posttest Control Group Design. From the number of students, several students were randomly selected who were then combined into new groups. Some students were grouped into the experimental group and several other students are grouped into a control group. Of the two groups were given two different treatments. The sampling technique used was simple random sampling. The research population was all SMP Mathla'ul Anwar Global School students in the $2019 / 2020$ school year and the research sample was in seventh grade.

\section{RESULTS AND DISCUSSION}

Quantitative data processing was done using SPSS version 20.0 for Windows software. Data obtained from 24 students of seventh-grade junior high school in Pandeglang, with 14 
students in the experimental group and ten students in the control group. The analyzed data is data beginning students' mathematical abilities obtained from mid-term assessments (PTS) in the second semester. Meanwhile, the data on students' mathematical problem-solving abilities were obtained from the pretest and posttest data to see each group's differences.

Table 1. Research Sample Distribution

\begin{tabular}{cccc}
\hline $\begin{array}{c}\text { Mathematical Initial } \\
\text { Ability (KAM) }\end{array}$ & $\begin{array}{c}\text { Experimental } \\
\text { Group }\end{array}$ & $\begin{array}{c}\text { Control } \\
\text { Group }\end{array}$ & Sum \\
\hline High & 2 & 2 & 4 \\
Medium & 10 & 6 & 16 \\
Low & 2 & 2 & 4 \\
Total & 14 & 10 & 24 \\
\hline
\end{tabular}

Table 1 describes the distribution of the number of samples in each group, either the experimental or control group, based on the students' criteria mathematical initial abilities. The experimental group had two students with high mathematical initial ability, ten students are in medium level mathematical initial ability, and two students in low level. The total for the experimental group was 14 students as a sample in this study. While the control group total sample of 10 students with 2 students with high mathematical initial ability, six students are in medium level mathematical initial ability, and the mathematical-initial ability of 2 students is low.

The pretest students' implementation was given the same question, which is done in the initial pretest-posttest but research conducted after the study. The pretest questions consisted of 5 problem-solving questions given to students to see the RME approach's effect on mathematical problem-solving abilities. The following will be presented descriptive statistics score pretest and posttest students' mathematical problem-solving ability. Calculations can be seen in the attachment.

Table 2. Descriptive Statistics of Mathematical Problem-Solving Ability

\begin{tabular}{clcccc}
\hline $\begin{array}{c}\text { Mathematical Initial } \\
\text { Ability (KAM) }\end{array}$ & Data & \multicolumn{2}{c}{ Experimental } & \multicolumn{2}{c}{ Control } \\
\hline \multirow{4}{*}{ All Ability } & Pretest & Posttest & Pretest & Posttest \\
& Mean & 14 & 14 & 10 & 10 \\
& Min & 27,92 & 51,57 & 41,80 & 39,80 \\
& Max & 58,00 & 33,00 & 26,00 & 20,00 \\
& SD & 9,32 & 78,00 & 72,00 & 70,00 \\
& N & 2 & 14,84 & 15,36 & 17,97 \\
& Mean & 56,00 & 2 & 2 & 2 \\
& Minh & 54,00 & 72,00 & 68,50 & 69,00 \\
& Max & 58,00 & 70,00 & 65,00 & 68,00 \\
& SD & 2,82 & 2,82 & 72,00 & 70,00 \\
& & 2,00 & 4,94 & 1,41 \\
\hline
\end{tabular}




\begin{tabular}{clcccc}
\multirow{4}{*}{ Medium } & N & 10 & 10 & 6 & 6 \\
& Mean & 36,50 & 49,20 & 38,00 & 35,42 \\
& Min & 28,00 & 33,00 & 32,00 & 30,00 \\
& Max & 42,00 & 78,00 & 45,00 & 50,00 \\
& SD & 4,83 & 14,14 & 4,89 & 8,69 \\
Low & N & 2 & 2 & 2 & 2 \\
& Mean & 27,00 & 43,00 & 26,50 & 21,00 \\
& Min & 27,00 & 40,00 & 26,00 & 20,00 \\
& Max & 27,00 & 46,00 & 27,00 & 22,00 \\
& SD & 0,00 & 4,24 & 0,70 & 1,41
\end{tabular}

The ideal maximum score for pretest and posttest is 100

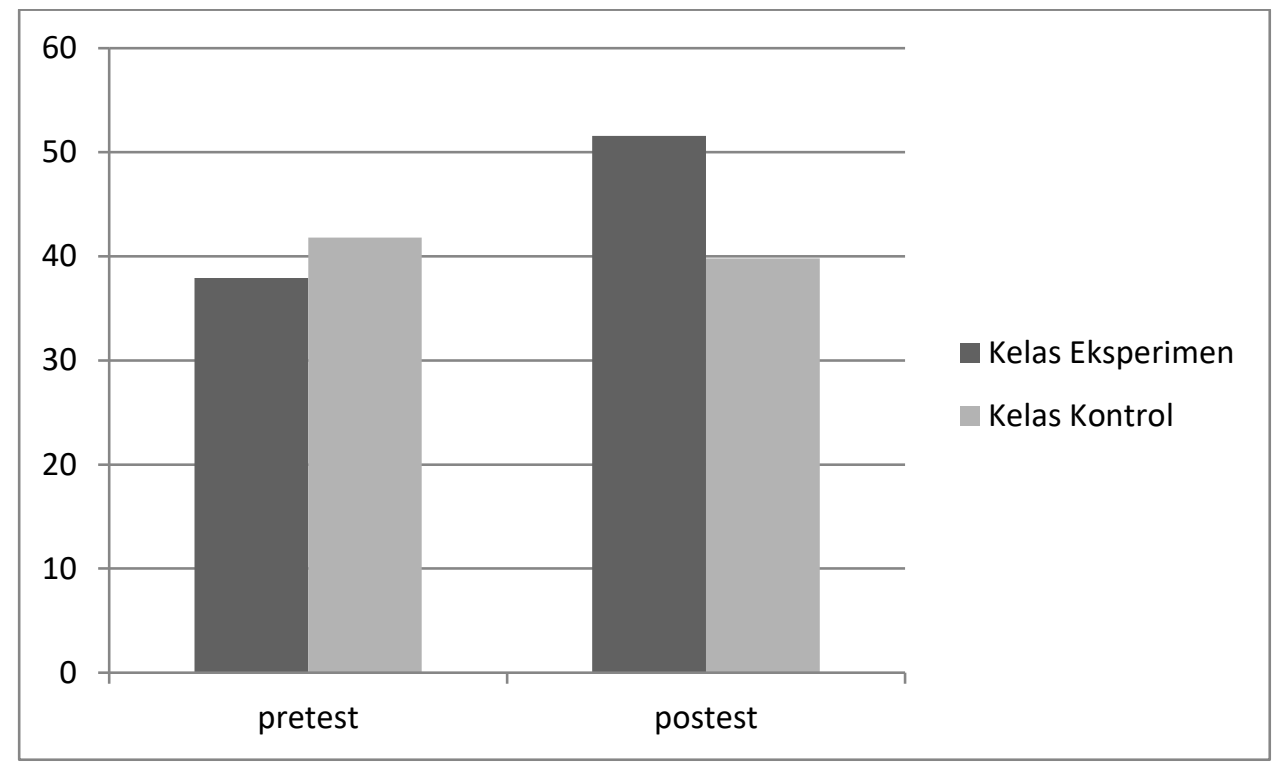

Diagram 1. Average Pretest and Posttest

Based on the bar chart above picture, can be seen that the average pretest results in the experimental group and the control group the difference is not too far away, while the average posttest results in the experimental group and the control group differences looked much different from the descriptive statistical analysis in the form of tables and diagrams.

Table 3. Two-Way Analysis of Variance (ANOVA) of Mathematical Problem-Solving Ability

\begin{tabular}{lccccc}
\hline \multicolumn{1}{c}{ Source } & $\begin{array}{c}\text { Type III Sum of } \\
\text { Squares }\end{array}$ & Df & Mean Square & $\boldsymbol{F}$ & Sig. \\
\hline Learning Approach & 632,596 & 1 & 632,596 & 5,059 & 0,037 \\
KAM & 3339,980 & 2 & 1669,990 & 13,354 & 0,000 \\
Learning Approach * KAM & 180,675 & 2 & 90,338 & 0,722 & 0,499 \\
\hline
\end{tabular}


a. The P-Value for the learning approach with a Sig value that is smaller than $\alpha$, then $\mathrm{HO}$ is rejected. With the Sig value of the learning approach 0.037 ; then $0.037<0.05$ so that it can be concluded that the mathematical problem-solving ability of students who used the RME approach is better than the students who used the scientific approach in terms of mathematical-initial ability.

b. The P-Value for the learning approach * KAM with a bigger Sig value than $\alpha$, then $\mathrm{HO}$ is accepted. With the Sig value of the learning model 0.499; then 0.499>0.05, it can be concluded that there was no interaction between applying the learning approach and students' mathematical-initial abilities in their effect on their mathematical problemsolving abilities.

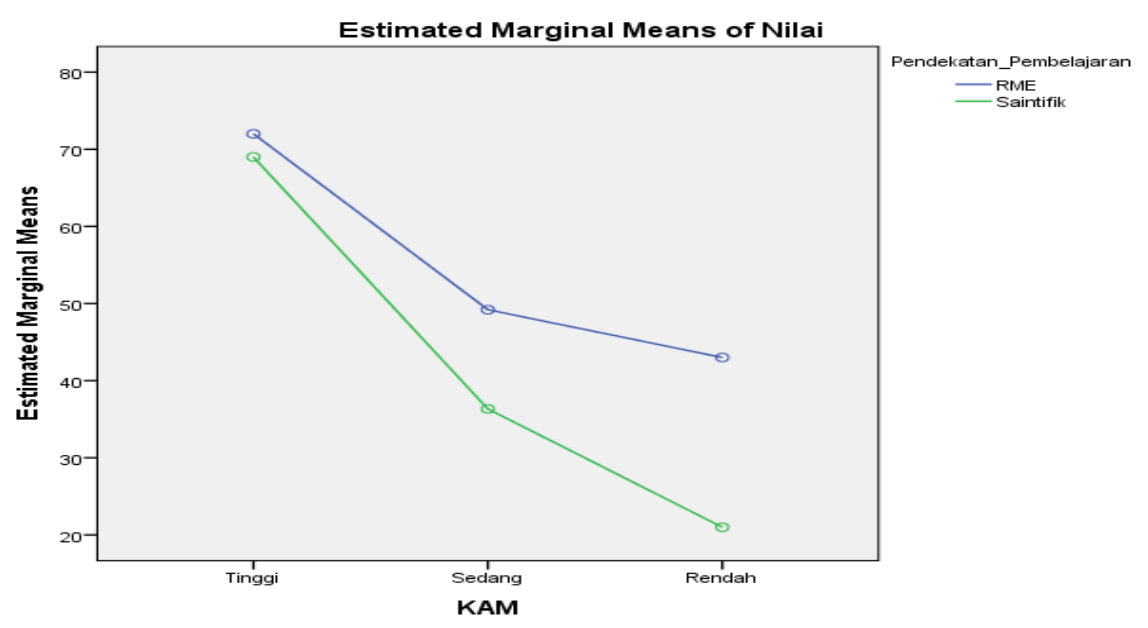

Figure 2. Interaction Between Learning Approaches and KAM to Mathematical Problem-Solving Ability

The diagram above shows that there is no interaction between the learning approach and students' KAM towards the achievement and improvement of mathematical problemsolving abilities. In other words, the RME learning approach factor has a very strong influence compared to the scientific approach in every initial mathematical ability. It means that the RME learning approach is not jointly with the scientific approach trying to improve mathematical problem-solving abilities in each of their initial mathematical abilities.

The research results and the results of the calculations show that there is a positive influence in applying the RME learning approach. Supported by Susanti \& Rustam's research (2018) RME Model used in teaching students mathematical reasoning skills is better than students taught using a direct learning model. According to Gravemeijer \& Doorman (1999), 
$\mathrm{RME}$ is about teaching and learning mathematics contextually where the problem context itself is the basis for progressive mathematization. Through mathematizing, students develop informal context-specific solution strategies for situations based on real experiences.

Students experience a psychological process between environmental and personal interactions in this realistic experiential process, resulting in changes in knowledge, understanding, and problem solving either through experience, practice or practice. It relates to Piaget's theory presented by Anidar (2017) that children can mentally do something that previously could only be done physically and can reverse concrete operations at the concrete operational stage.

However, in the next stage, children have started to think about experiences outside of concrete experiences and think about them more abstractly, idealistically, and logically. The final stage of Piaget's theory is related to the RME approach to the mathematical process. One of the RME concepts, according to Freudenthal includes (Suryanto, 2007) mathematics, which means that science is no longer just a collection of experiences. It involves organizing experiences using mathematics, which is called mathematizing (mathematicalization or mathematics).

Students' thinking concretely from mathematical experiences in which reality is included in horizontal mathematics. In the next process, students will think abstractly where they gain experience outside of concrete experiences. Based on the previous explanation, it can be said that RME is related to Piaget's learning theory.

In this study, the hypothesis test was carried out; after the data were analyzed, the test results were obtained. As a result, students who use the RME approach's mathematical problem-solving ability are better than students who use the scientific approach in terms of their initial mathematical abilities. It was mentioned by Kesumawati (2014) that in order for students to have good problem-solving abilities, meaningful mathematical comprehension skills are needed for each student. The research results conducted by Sugiman and Yaya S. Kusumah (2010) stated that the increase in KPMM for PMR students was higher than the increase in KPMM for PB students for all students and all school levels.

\section{CONCLUSION}

Based on the research results of the RME approach to students' mathematical problemsolving abilities in terms of students' mathematical initial abilities, the following conclusions Vol. 5, No. 1, January 2021, 35-46 
were obtained the mathematical problem-solving abilities of students who used the RME approach was better than students who used the scientific approach. There was no interaction between the learning approach and previous mathematical abilities (high, medium, low) on students' mathematical problem-solving abilities.

It is recommended that the RME approach be used as an alternative learning because the RME approach can foster students' mathematical problem-solving abilities. Researchers' developed material was only social arithmetic material, preferably for other researchers should develop it with more mathematical materials. It was necessary to carry out further research by considering students' ability level and level of education.

\section{REFERENCES}

Agus, R. N. (2010). Efektivitas Pembelajaran Matematika Melalui Pendekatan Realistics Mathematics Education (RME) Dengan Pemecahan Masalah dan Pendekatan Realistics Mathematics Education (RME) Ditinjau dari Gaya Belajar Siswa. Tesis tidak diterbitkan. Universitas Sebelas Maret.

Anisah, Hana, \& Mawaddah, S. (2015). Kemampuan Pemecahan Masalah Matematis Siswa Pada Pembelajaran Matematika Dengan Menggunakan Model Pembelajaran Generatif (Generatif Learning) di SMP. EDU-MAT: Jurnal Pendidikan Matematika, 3(2), 166-175.

Arikunto, S. (2006). Prosedur Penelitian Suatu Pendekatan Praktik. Edisi Revisi VI. Jakarta: Rineka Cipta.

Arikunto, S. (2009). Dasar-Dasar Evaluasi Pendidikan. Jakarta: PT Bumi Aksara.

Evendi, H. (2019). Pengaruh Model Pembelajaran Creative Problem Solving (CPS) Terhadap Kemampuan Pemecahan Masalah dan Kecemasan Matematis Siswa SMP Ditinjau dari Kemampuan Awal Matematis (KAM). Tesis tidak diterbitkan. UNTIRTA.

Fitriana, H. (2010). Pengaruh pendekatan pendidikan matematika realistik terhadap kemampuan pemecahan masalah matematika siswa. Skripsi UIN. Jakarta: Tidak diterbitkan.

Freudenthal, H. (1991). Revisiting mathematics education: China Lectures. Dordrecht, Netherlands: Springer Netherlands. DOI: https://doi.org/10.1007/0-306-47202-3.

Gafur, A. (1993). Desain Instruktusional. Jakarta: BPT IKIP Jakarta. 
Gravemeijer, K., \& Doorman, M. (1999). Context problems in realistic mathematics education: a calculus course as an example. Educational studies in mathematics, 39, 111-129. DOI: https://doi.org/10.1023/A:1003749919816.

Gravemeijer, K. (2008). RME theory and mathematics teacher education. In D. Tirosh, \& T. Wood. The International Handbook of Mathematics Teacher Education: Tools and processes in mathematics teacher education (pp. 283-302). Rotterdam, Netherlands: Sense Publisher. Retrieved from https://www.sensepublishers.com/media/1081-thehandbook-of-mathematics-teacher-education-volume-2.pdf.

Hendri, D., Zulkardi., \& Ilma, R. (2007). Pengembangan materi kesebangunan dengan pendekatan pmri di smp negeri 5 talang ubi. Jurnal Pendidikan Matematika, 1(2), 4655.

Hernawati, F. (2016). Pengembangan perangkat pembelajaran matematika dengan pendekatan PMRI berorientasi pada kemampuan representasi matematis. Jurnal Riset Pendidikan Matematika, 3(1), 34-44.

Kusumah, Y. S \& Sugiman. (2010). Dampak pendidikan matematika realistik masalah siswa SMP. Journal on Mathematics Education, 1(1), 41-51.

Kusumawati, N. (2013). Pengaruh Kemampuan Komunikasi dan Pemecahan Masalah Matematika terhadap Hasil Belajar Siswa dengan Pembelajaran Realistic Mathematic Education (RME). Jurnal Ilmiah Pendidikan Matematika, 1(1), 104-113.

Lestari, L., \& Surya, E. (2017). The Effectiveness of Realistic Mathematics Education Approach on Ability of Students' Mathematical Concept Understanding. International Journal of Sciences: Basic and Applied Research, 34(1), 91-100.

Oftiana, S., \& Saefudin, A. A. (2017). Pengaruh pendekatan pembelajaran matematika realistik indonesia (PMRI) terhadap kemampuan pemecahan masalah matematika siswa kelas VII smp negeri 2 srandakan. Jurnal Matematika dan Pembelajaran, 5(2), 293-301.

PISA. (2015). PISA 2015 Result in Focus. Better Policies for Better Lives: OECD.

Posamentier, S.A \& Krulik. (2009). Problem Solving in Mathematics Grades 3-6. California: United States of America.

Rahmah, E. (2019). Pengaruh Pendekatan Pembelajaran Realistic Mathematics Education (RME) Terhadap Kemampuan Pemahaman Matematis dan Motivasi Belajar Siswa 
Sekolah Dasar Ditinjau Berdasarkan Kemampuan Dasar Berhitung. Tesis tidak diterbitkan. UNTIRTA.

Shodikin, A. (2015). Kemampuan Awal Matematis Siswa Dan Pembelajaran Dengan Strategi Abduktif-Deduktif Terhadap Peningkatan Kemampuan Penalaran dan Disposisi Matematis Siswa. Jurnal Inovasi Pendidikan dan Pembelajaran Matematika, 1(1), 61-72. Simanulang, J. (2014). Pengembangan Bahan Ajar Materi Himpunan Konteks Laskar Pelangi Dengan Pendekatan Pendidkan Matematika Realistik Indonesia (PMRI) Kelas VII Sekolah Menengah Pertama. Jurnal Pendidikan Matematika, 8(1), 43-54.

Simanullang, J., Darmawijoyo., \& Somakim. (2013). Pengembangan Bahan Ajar Himpunan Dengan Pendekatan Pendidikan Matematika Realistik Indonesia Kelas VII Sekolah Menengah Pertama. Jurnal Pendidikan Matematika, 7(1), 11-18.

Soedjadi, R. (2007). Inti Dasar-Dasar Pendidikan Matematika Realistik Indonesia. Jurnal Pendidikan Matematika, 1(2), 1-10.

Sufairoh. (2016). Pendekatan Saintifik \& Model Pembelajaran K-13. Jurnal Pendidikan Profesional, Volume 5

Sugiman, Kusumah, Y.S, \& Sabandar, J. (2009). "Pemecahan Masalah Matematik Dalam Matematika Realistik", Universitas Negeri Yogyakarta.

Sugiyono. (2011). Metode Penelitian Kuantitatif Kualitatif R\&D. Bandung: Alfabeta.

Suratmi, S., \& Purnami, A.S. (2017). Pengaruh Strategi Metakognitif Terhadap Kemampuan Pemecahan Masalah Matematika Ditinjau Dari Persepsi Siswa Terhadap Pelajaran Matematika. UNION: Jurnal.

TIMSS. (2015). Contextual Framework Chapter 3. TIMSS.

Trisnawati, D., Putri, R.I.I., \& Santoso, B. (2015). Desain pembelajaran materi luas permukaan prisma menggunakan pendekatan PMRI bagi siswa kelas VIII. Jurnal Kreano, 6(1), 7685.

Umar, W. (2016). Strategi Pemecahan Masalah Matematis Versi George Polya dan Penerapannya Dalam Pembelajaran Matematika. Jurnal Pendidikan Matematika KALAMATIKA, 1(1), 59-70.

Uno, H. (2008). Model Pembelajaran: Menciptakan Proses Belajar Mengajar yang Kreatif dan Efektif. Jakarta: Bumi Aksara. 
Wijayanti, K., Riyanto., \& Wardono. (2014). Keefektivan PMRI berbantuan alat peraga terhadap kemampuan pemecahan masalah serupa PISA pada kelas VII. Jurnal Kreano 5(1), 33-40. 